\title{
Bacteriological Quality of Dried Sliced Beef (Kilishi) Sold In Ilorin Metropolis
}

\author{
RAJI, A I \\ Department of Biological Sciences, University of Ilorin, P. M. B. 1515. Ilorin. \\ Kwara State. Nigeria. \\ E-Mail: abdulmajeedraji@yahoo.com
}

\begin{abstract}
The bacteriological quality of dried sliced beef (kilishi) obtained from three selling points in Ilorin metropolis was determined in order to ascertain its safety. The total bacterial count, Enterobacteriaceae count, Staphylococcus aureus count and E.coli counts were used as index of bacteriological quality. Samples from Oja-gboro had the highest total bacterial count of $3.5 \times 10^{4} \mathrm{cfu} / \mathrm{g}$; Enterobacteriaceae count of $2.9 \times 10^{4}$ $\mathrm{cfu} / \mathrm{g} ; S$. aureus count of $2.05 \times 10^{4} \mathrm{cfu} / \mathrm{g}$ and E.coli count of $3.8 \times 10^{1} \mathrm{cfu} / \mathrm{g}$. Bacterial species isolated from the samples were $S$. aureus, Pseudomonas species, E. Coli, Klebsiella species and B. subtilis. The high bacterial count and diversity of bacterial isolates from the samples tested is an indication of its low bacteriological quality, and this can make it a potential source of food infection. Standard hygienic practices are therefore recommended at both pre- and post-production stages. @JASEM
\end{abstract}

Dried sliced beef (kilishi), a local meat product, is a popular meat variety in Northern Nigeria. It is prepared by cutting raw meat into flat forms, sundry, roast and spice to add flavour and taste. Meat is one of the most perishable foods, and its composition is ideal for the growth of a wide range of spoilage bacteria (Mayr et al., 2003). Public concern has risen due to numerous food scandals such as those surrounding bovine spongiform encephalopathy and foot-and-mouth disease epidemics (Ellis and Goodacre, 2001; Pickrell and Enserink, 2001), and food-borne diseases have therefore remained a substantial burden (Tauxe, 2002). The widespread distribution of meat products therefore, makes the consequences of contamination with food poisoning microorganisms more serious (Macrae et al.,1993). The state of health of animals prior to slaughtering and the prevailing circumstance in the slaughter can contribute to the quality of meat from such animals (Whyte et al.,2004). In Nigeria, particularly in rural communities and small towns, slaughtering of animals usually takes place under very unhygienic conditions. This, coupled with the high ambient temperature, high humidity, shortage of portable water and poor handling practices disposes meat product to microbial contamination and rapid deterioration (Bender, 1992).

The aim of this study was to determine the bacteriological quality of dried sliced beef (kilishi) using classical microbiological techniques. This is important because this meat product serves as readyto-eat snacks and therefore could be a source of infection if contaminated.

\section{MATERIALS AND METHODS}

Sampling: Freshly prepared dried sliced meat samples $(100 \mathrm{~g}$ each) were collected from three well known selling points in Ilorin metropolis namely:
Eyenkorin (Selling Point A), Oja- gboro (Selling Point B) and Sango area (Selling Point C). The health status of the animals used for preparing the meat product was not established and only the already prepared product was analysed. The samples were transported to the laboratory in clean, sterile aluminium foil immediately after collection.

Determination of moisture content: Ten grams of dried sliced meat sample from each selling point was weighed and dried in the oven at $80^{\circ} \mathrm{C}$ to a constant weight. The moisture content was determined as the difference between the weight of fresh samples and that of the sample after drying to a constant weight. This was expressed as percentage (\%) of the total weight of the sample.

$$
\mathrm{MC},(\%)=\frac{\mathrm{LWS} \times 100}{\mathrm{WFS}}
$$

where $\mathrm{MC}=$ Moisture content $(\%)$, LWS $=$ Loss in weight (of sample) and WFS = weight of fresh sample

Microbiological analysis: Twenty-five grams of each dried sliced meat sample was aseptically weighed and transferred to sterile blender (Lab Blender 400 series, UK) to which $225 \mathrm{ml}$ of a sterile solution consisting of $0.85 \% \mathrm{NaCl}$ and $0.1 \%$ peptone (Oxoid) was added and homogenized for 1 minute. Decimal dilutions in $0.85 \% \mathrm{NaCl}-0.1 \%$ peptone were prepared, and $0.1-\mathrm{ml}$ samples of appropriate dilutions were spread on Nutrient agar (Oxoid), MacConkey agar (Oxoid) and Baird-Parker agar (Oxoid) for the enumeration of total bacteria, Enterobacteriaceae, and Staphylococcus aureus respectively. 
Total aerobic count: For Total bacterial counts, $0.1 \mathrm{ml}$ of $10^{-3}$ dilutions was inoculated onto sterile nutrient agar plates and spread on the surface using sterile bent glass rod. Inoculated plates were incubated at $37^{\circ} \mathrm{C}$ for $48 \mathrm{hr}$ before colonies were counted and reported as colony forming units $/ \mathrm{g}$ $(\mathrm{cfu} / \mathrm{g})$.

Enterobacteriaceae counts: For Enterobacteriaceae counts, $0.1 \mathrm{ml}$ of $10^{-3}$ dilutions was transferred to sterile MacConkey agar plates and spread on the surface using sterile bent glass rod. Inoculated plates were incubated at $37^{\circ} \mathrm{C}$ for $24 \mathrm{hr}$ before colonies were counted and reported as colony forming units $/ \mathrm{g}$ (cfu/g).

E. coli Enumeration: E. coli was enumerated from blended samples using a method previously described (NIPHEP, 1994). An aliquot of $1.0 \mathrm{ml}$ of each dilution was spread in duplicate on surface mounted membrane filters (Gelman Sciences, USA) which were placed on the surface of tryptone bile agar plates (Oxoid). The plates were then incubated for $24 \mathrm{hr}$ at $44^{\circ} \mathrm{C}$. After incubation, the membrane filters were removed from the agar plates and placed on equivalent sized filter papers (Whatman International,UK) that had been soaked in $2 \mathrm{ml}$ volumes of indole detection reagent $(5 \% p$ dimethylaminobenzaldehyde dissolved in $1 \mathrm{~N} \mathrm{HCl}$ ) (Sigma- Aldrich, UK). Indole positive colonies developed a pink-purple coloration on the membrane filter surfaces within $20 \mathrm{~min}$ and were presumptively counted as E. coli

Staphylococcus aureus Enumeration: S. aureus were presumptively enumerated on the basis of their appearance on Baird-Parker agar (Oxoid). An aliquot of $0.1 \mathrm{ml}$ volumes of relevant dilutions were spread on duplicate agar plates using sterile bent glass rod. The inoculated plates were incubated at $37^{\circ} \mathrm{C}$ for $48 \mathrm{hr}$. Samples of $10-15$ colonies from each batch of experiment were confirmed as coagulase positive $S$. aureus using the agglutination test.

Identification of Bacterial isolates: Representative bacterial colonies from the inoculated agar plates were picked and transferred onto nutrient agar slants and stored at $4^{\circ} \mathrm{C}$ prior to use. The isolates were identified based on colonial morphology and biochemical characteristics. The biochemical tests carried out are: Gram staining; Spore staining; Capsule staining; Motility; Catalase; Coagulase; Indole; Citrate utilisation; MR-VP; Oxidase; urease; Gelatin hydrolysis; Oxidase and Sugar fermentation.

\section{RESULTS AND DISCUSSION}

The moisture content of the dried sliced meat samples collected varied depending on the point of collection. Samples from selling point B had the highest moisture content of $26 \%$ followed by samples from selling point $\mathrm{C}$ with $25 \%$ while samples from selling point A had the least moisture content of $19 \%$ (Table 1). Moisture content of food products have however been shown to contribute significantly to their microbial flora (Prescott, et al., 2002). The bacterial quality of the samples also varied with the selling points, with samples from Point B generally having the highest count (Table 2). The total bacterial count for the samples ranged from $2.4 \times 10^{4}$ to $3.5 \mathrm{X}$ $10^{4} \mathrm{cfu} / \mathrm{g}$, the Enterobacteriaceae count ranged from $2.61 \times 10^{4}$ to $2.90 \times 10^{4} \mathrm{cfu} / \mathrm{g}$. S. aureus count ranged from $1.6 \times 10^{4}$ to $2.05 \times 10^{4} \mathrm{cfu} / \mathrm{g}$. E. coli count from all the samples was the least, ranging from $1.2 \times 10^{1}$ to $3.8 \times 10^{1} \mathrm{cfu} / \mathrm{g}$. A total of five bacterial species namely: Staphylococcus aureus, Pseudomonas aeruginosa, Escherichia coli, Klebsiella pneumoniae and Bacillus subtilis belonging to different genera were isolated from all the samples analysed (Table 3).

The bacterial counts of the dried sliced meat samples studied were generally high, and a heterogenous flora with respect to microbial numbers and composition was observed. This will not be unconnected with the type of meat used and the processing of the meat that is usually carried out un-hygienically. However, the application of high temperature during roasting and the process of drying of the meat were expected to have reduced the bacterial load of the meat product. The relatively high bacterial counts despite these processes suggest possible post-production contamination.

Because meat tissue surfaces carry considerable bacterial loads, initial meat contamination flora have been reported to be heterogeneous with respect to microbial numbers and composition (Jay, 1996 ; Upmann et al., 2000). With regards to moisture content and bacteriological analysis, samples from Oja-gboro had higher count than samples from Eyenkorin and Sango. However, the moisture content of the dried sliced meat product had reduced considerably, as the moisture content of raw beef is reported to be between 60-65\% (Prescott, et al.,2002). The high $S$. aureus count recorded for all the samples, is an indication of possible contamination from human sources. $S$. aureus is a normal flora of the skin of man and can be transmitted from person to product through unhygienic practices (Postgate, 2000). Enterotoxin producing strains of $S$. aureus have been isolated from food handlers and the possibility of their transmission highlighted (Adesiyun, et al., 1986). 
Staphylococcus aureus enterotoxin A (SEA) is a leading cause of food intoxication (Rasooly et al., 1997). SEA is an extremely potent gastrointestinal toxin; as little as $100 \mathrm{ng}$ is sufficient to cause symptoms of intoxication (Evenson, et al., 1988). High Enterobacteriaceae count of the samples is an indication of possible contamination from enteric sources (Brown and Baird-Parker, 1982). Also E. coli count of between $1.2 \times 10^{1}$ and $3.8 \times 10^{1} \mathrm{cfu} / \mathrm{g}$ for the samples from all the sources is high. This is of public health concern considering the role of E.coli in foodborne infection (Goepfert, 1976). The isolation of Pseudomonas and Klebsiella species from some of the ready-to-eat dried sliced meat samples tested is an indication of possible post production contamination as these organisms are expected to have been destroyed during the high temperature treatment of roasting and drying. However, gram negative aerobic rod shaped bacteria especially pseudomonas have been reported as dominant meat spoilage organisms (Dainty and Mackey, 1992; Borch et al., 1996). The isolation of B. subtilis from the samples could be as a result of the ubiquitous nature of the organism and its endospore forming ability, which confers resistance to it (Drobniewski, 1993). To ensure bacteriological quality of meat product, the quality of the raw meat used for its preparation, the environment where this meat is been slaughtered and processed and the general health of the meat should be taken in to consideration (FAO, 1990). The composition of the meat spoilage flora is greatly influenced by the storage conditions, such as temperature and type of packaging (Tsigarida and Nychas, 2001). Also the health of the workers should be monitored as they can serve as potential carriers of pathogenic organisms.

Table 1: Percentage moisture content of dried sliced meat samples from three different selling points in Ilorin metropolis.

\begin{tabular}{cc}
\hline $\begin{array}{c}\text { Selling } \\
\text { locations }\end{array}$ & $\begin{array}{c}\text { Moisture } \\
\text { content }(\%)\end{array}$ \\
\hline Selling Point A & 19 \\
Selling Point B & 26 \\
Selling Point C & 25 \\
\hline Data: Mean of duplicate determinations.
\end{tabular}

Table 2: Bacteriological quality of dried sliced meat samples from three different selling points in Ilorin metropolis.

\begin{tabular}{|lllll|}
\hline Selling locations & \multicolumn{3}{c|}{ Bacterial Count (cfu/g) } \\
\hline & S.aureus & & Enterobacteriaceae & E. coli \\
\hline & & & & \\
\hline Selling Point A & $2.4 \times 10^{4}$ & $2.81 \times 10^{4}$ & $1.2 \times 10^{1}$ & $1.91 \times 10^{4}$ \\
\hline Selling point B & $3.5 \times 10^{4}$ & $2.9 \times 10^{4}$ & $3.8 \times 10^{1}$ & $2.0 \times 10^{4}$ \\
\hline Selling Point C & $2.8 \times 10^{4}$ & $2.6 \times 10^{4}$ & $1.7 \times 10^{1}$ & $1.6 \times 10^{4}$ \\
\hline
\end{tabular}

Data: Mean of duplicate determinations. TBC: Total bacterial count.

Table 3: Identification of Bacterial isolates based on colonial morphology and biochemical characteristics

\begin{tabular}{|c|c|c|c|c|c|}
\hline \multirow{2}{*}{$\begin{array}{l}\text { Biochemical } \\
\text { Tests }\end{array}$} & \multicolumn{5}{|c|}{ Bacterial isolates. } \\
\hline & S.aureus & P.aeruginosa & E.coli & K.pneumoniae & B. subtilis \\
\hline Gram Stain & + & - & - & - & + \\
\hline Spore stain & - & - & - & - & + \\
\hline $\begin{array}{l}\text { Capsule } \\
\text { stain }\end{array}$ & - & - & - & + & - \\
\hline Motility test & - & + & + & - & - \\
\hline $\begin{array}{l}\text { Coagulase } \\
\text { test }\end{array}$ & - & - & - & - & - \\
\hline Oxidase test & + & + & + & - & - \\
\hline Catalase test & + & + & + & - & + \\
\hline Voges & - & - & - & + & - \\
\hline Proskauer & & & & & \\
\hline Methyl Red & - & + & + & - & - \\
\hline Indole test & - & - & + & - & - \\
\hline $\begin{array}{l}\text { Gelatin } \\
\text { liquefication }\end{array}$ & - & + & & + & + \\
\hline $\begin{array}{l}\text { Citrate } \\
\text { utilisation }\end{array}$ & - & - & - & - & - \\
\hline Urease & - & ND & + & ND & ND \\
\hline
\end{tabular}




\section{REFERENCES}

Adesiyun, A. A.; Raji, I. and Yobe, V. (1986). Enterotoxigenicity of Staphylococcus aureus from anterior nares of dinning hall workers. Journal of Food Protection. 49: 955 - 957.

Bender, A. (1992). Meat and meat products in human nutrition in developing countries. Commissioned jointly by the Animal Production and Health Division and the Food Policy and Nutrition Division of FAO, Rome.

Borch, E., M. L. Kant-Muermans, and Y. Blixt. (1996). Bacterial spoilage of meat and cured meat products. Int. J. Food Microbiol. 33: 103-120.

Brown, M.H., Baird-Parker, A.C., (1982). The microbiological examination of meat. In: Brown, M.H. (Ed.), Meat Microbiology. Applied Science Publishers, London, pp. 423-520.

Dainty, R. H., and B. M. Mackey. (1992). The relationship between phenotypic properties of bacteria from chillstored meat and spoilage processes. J. Appl. Bacteriol. Symp. Suppl. 73: 103S-114S.

Drobniewski, F. A. (1993). Bacillus cereus and related species. Clin. Microbiol. Rev. 6: 324-338.

Ellis, D. I., and R. Goodacre. (2001). Rapid and quantitative detection of the spoilage of muscle foods: current status and future trends. Trends Food Sci. Technol. 12: 414-424.

Evenson, M. I., M. W. Hinds, R. S. Bernstein, and M. S. Bergdoll. (1988). Estimation of human dose of staphylococcal enterotoxin A from a large outbreak of staphylococcal food poisoning involving chocolate milk. Int. J. Food Microbiol. 7:311-316

FAO, (1990). Manual on simple methods of meat preservation. FAO ANIMAL PRODUCTION AND HEALTH PAPER 79. FOOD AND AGRICULTURE ORGANIZATION OF THE UNITED NATIONS Rome

Goepfert, J.M., (1976). The aerobic plate count, coliform and Escherichia coli content of raw ground beef at retail level.

J. Food Prot. 39, 175-178.
Jay, J. M. (1996). Modern food microbiology, 5th ed. Chapman \& Hall, NewYork, N.Y.

Macrae, R., Robinson, R.K. and Sailer, M.J. (1993). Encyclopedia of food science. Food Technology and Nutrition. $6: 4233$ - 4236

Mayr, D; Margesin, R., Klingsbichel, E., Hartungen, E., D. Jenewein, D., Schinner, F. and Ma"rk1, T.D (2003). Rapid Detection of Meat Spoilage by Measuring Volatile Organic Compounds by Using Proton Transfer Reaction Mass Spectrometry. Appl. Env. Microbiol. 69 : 4697 - 4705.

NIPHEP (1994). Enumeration of Escherichia coli in reference materials for food microbiology, BCR/Food Trial 6, in Report

281008005. National Institute of Public Health and Environmental Protection, Bilthoven, The Netherlands, pp. 35-39

Pickrell, J., and M. Enserink. (2001). Foot-and-mouth disease: UK outbreak is latest in global epidemic. Science 291: 1677.

Postgate J.R. (2000). Microbes and Man. Oxford, UK; New York: Cambridge University Press. 373p.

Prescott, L. M.; Harley, J.P. and Klein, D.A. (2002). Microbiology. 5th Edition. McGraw-Hill . London. pp. $963-971$

Rasooly, L.; Rose, N.R.; Shah, D.B. and Rasooly, A. (1997). In Vitro Assay of Staphylococcus aureus Enterotoxin A Activity in Food. Appl. Env. Microbiol. 63 : 2361 - 2365

Tauxe, R. (2002). Emerging foodborne pathogens. Int. J. Food Microbiol. 78:31-41.

Tsigarida, E., and G. J. E. Nychas. 2001. Ecophysiological attributes of a Lactobacillus sp. and a Pseudomonas sp. on sterile beef fillets in relation to storage temperature and film permeability.

J. Appl. Microbiol. 90: 696-705.

Upmann, M., P. Paulsen, S. James, and F. J. M. Smulders. (2000). The microbiology of refrigerated meat. Fleischwirtschaft 3: 38-45.

Whyte, P., McGill, K., Monahan, C., and Collins, J.D. (2004). The effect of sampling time on the levels of mico-organisms recovered from broiler carcasses in a commercial slaughter plant.

Food. Microbiol. 21, 59 - 65. 